\title{
The Influence of the Addition of Pectin Concentrations on Physical and Chemical Properties of Functional Food of Nori derived from Cassava Leaves
}

\author{
Gesti Annisa Innayatuhibbah ${ }^{a}$, Nur Wahyu Sholitan ${ }^{b, *}$, Afrianita Fitriani ${ }^{c}$, Desi Anisa Nurlaily ${ }^{d}$, \\ dan Esti Widowati ${ }^{\mathrm{e}}$
}

\author{
${ }^{\text {a}}$ Program in Agribusiness, Faculty of Agriculture, Universitas Sebelas Maret \\ b,d Three Year Diploma Program in Agricultural Product Processing Technology, Universitas Sebelas Maret \\ ${ }^{\mathrm{c}}$ Program in Agricultural Counseling and Communication, Faculty of Agriculture, Universitas Sebelas Maret \\ ${ }^{e}$ Program in Food Science and Technology, Faculty of Agriculture, Universitas Sebelas Maret \\ *Email: nurwasholitan@gmail.com
}

\begin{abstract}
The present research sought to find out appropriate pectin concentrations in the production of nori derived from cassava leaves, and the influence on chemical properties of the produced nori. The research is useful to optimize the use of cassava leaves as alternative raw materials for the production of nori seaweed. Pectin with concentrations of $1 \%, 3 \%$, and $5 \%$ was added in boiled and blended cassava leaves, with the addition of 1 gram of salt and $100 \mathrm{ml}$ of water. Such processes as molding, drying, and frying were subsequently done. The given pectin concentrations were proved to exert an influence on water concentration and antioxidant activities of functional food of nori derived from cassava leaves. The functional food of nori derived from cassava leaves appropriate with commercial nori seaweed is that with the addition of pectin concentration of $3 \%$.
\end{abstract}

Keywords: Antioxidant, Cassava leaves, Nori, Pectin

\section{Introduction}

Nori is sheets of dried or roasted seaweed [1]. According to [2], in addition to being used as ingredient (wrap) of sushi, nori can be directly consumed as a snack. The consumption of nori in Indonesia is nowadays increasing. All persons from children to adults enjoy consuming nori as both snack and coating of sushi. All this time, nori has only been being produced in Japan, Korea, and China due to its raw material of red seaweed-a species of Porphyra. Porphyra cannot be found in Indonesia because it grows in subtropical climate. Indonesia, therefore, should import considerable quantities of nori to fulfil the demand of nori. Therefore, alternative raw materials - aside from Porphyra, which are easily found in Indonesia should be discovered. Cassava leaves, one of raw materials easily found in Indonesia, may be taken into consideration.

The availability of cassava leaves is associated with production of cassava plants. In Central Java province, cassava plant is the second most extensive cultivated plant in Indonesia. Cassava products in rural areas of such province are mostly used as food with source of carbohydrates. In areas of tapioca industry, cassava leaves are considered as a waste product of the cassava agricultural production system. The availability of cassava leaves is increasing, along with the expanded farmlands and the increase in productivity of cassava plants. Almost $10-40 \%$ of parts of cassava plants comprises leaves. Dried cassava leaves generally have protein content of $20-27 \%$ [3].

The aim of the research was to find out the influence of the addition of pectin and of various pectin concentrations in the production of nori derived from cassava leaves on chemical properties of the functional food of the nori that produced from cassava leaves.

\section{Research Methodology}

\subsection{Materials}

The primary materials of the research included cassava leaves collected from Mr. Paiman's Karanganyar's farmer business groups, pectin obtained from Yogyakarta's store which sells pectin, and salt from Surakarta's Pasar (market) Gede.

\subsection{Instruments}

Instruments used to make functional food of nori derived from cassava leaves consisted of a blender, a pan, a stove, a baking pan, plastics and a cabinet dryer. Meanwhile, instruments for analysis included an analytical balance, the Memmert oven, a desiccator, a cuvette, a $10 \mathrm{ml}$ measuring pipette, a $1 \mathrm{ml}$ measuring pipette, a test tube, a volumetric flask, and a UV-VIS Spectrophotometer.

\subsection{Research Procedures}

The present research was divided into two stages, namely preliminary research and primary research.

\subsubsection{Preliminary research}

A preliminary research on the production of functional food of nori derived from cassava leaves was carried out to determine the selected formulation of the functional food of nori derived from cassava leaves using sensory testing (the hedonic scale test) [4]. The testing was intended to 
determine the best formulation in the production of functional food of nori derived from cassava leaves for the primary research. The results of the testing indicated that the formulation with the addition of pectin concentration of $3 \%$ was decided as the best sample based on its best results on flavor, texture, and overall components.

\subsubsection{Primary research}

The functional food of nori derived from cassava leaves was made firstly by separating cassava leaves from their petiole and washing them. Afterwards, the cassava leaves were boiled for 10 minutes and left to dry. Next, 50 grams of the cassava leaves were accurately weighed. Then, pectin concentration of $1 \%, 3 \%$, and $5 \%$, as well as 1 gram of salt and $100 \mathrm{ml}$ of water were added to each sample. The mixture was later blended to a soft texture. After that, it was spread in a baking pan and dried using a cabinet dryer at temperature of $50^{\circ} \mathrm{C}$ for 12 hours. Having been dry, the functional food of nori derived from cassava leaves was finally fried.

A completely randomized design with one primary factor, the increase in pectin concentration on the production of the functional food of nori derived from cassava leaves, was employed in the research. The obtained data were then statistically analyzed using one way analysis of variance (ANOVA). Next, the difference between treatments was tested using Duncan's Multiple Range Test (DMRT) on significance level $(\alpha)$ of 0.05 .

\section{Result and Discussion}

\subsection{Test for water concentration [5]}

Table 1 signifies that the addition of pectin in the production of functional food of nori derived from cassava leaves gave significant influence on the produced water concentrations. A sample of functional food of nori derived from cassava leaves with the addition of pectin concentration of $1 \%$ had the lowest water concentration $\left(2,47^{\mathrm{a}}\right)$, while that with the addition of pectin concentration of $5 \%$ was found to have the highest water concentration $\left(4,15^{\mathrm{c}}\right)$. Such increase in water concentration is in fact caused by the addition of hydrocolloids. The higher the hydrocolloid concentration, the more water bound in hydrocolloid chains [6].

Table 1. The Results of Test for Water Concentration of the Functional Food of Nori derived from Cassava Leave

\begin{tabular}{|l|l|}
\hline Sample & Water Concentration (\%) \\
\hline P 1\% & $2,47^{\mathrm{a}}$ \\
\hline P 3\% & $3,27^{\mathrm{b}}$ \\
\hline P 5\% & $4,15^{\mathrm{c}}$ \\
\hline
\end{tabular}

Description: P $1 \%=$ the addition of pectin concentration of $1 \%$ P $3 \%=$ the addition of pectin concentration of $3 \%$ $\mathrm{P} 5 \%=$ the addition of pectin concentration of $5 \%$

\subsection{Test for Antioxidant Activity [7]}

Table 2 reveals antioxidant activity of the functional food of nori derived from cassava leaves. The addition of pectin in the production of the functional food of nori derived from cassava leaves exerts a significant influence on the antioxidant activity. The functional food of nori derived from cassava leaves added with pectin concentration of $5 \%$ had the highest antioxidant activity of the three formulations. This fact makes sense since the added pectin is derived from orange peel extract. According to Friatna et al. (2011), orange peel contains antioxidant (ascorbic acid).

Table 2. The Results of Test for Antioxidant Activity of the Functional Food of Nori derived from Cassava Leaves

\begin{tabular}{|l|l|}
\hline Sample & Antioxidant Activity (\%) \\
\hline P 1\% & $76.52^{\mathrm{a}}$ \\
\hline P 3\% & $87.55^{\mathrm{b}}$ \\
\hline P 5\% & $87.94^{\mathrm{b}}$ \\
\hline
\end{tabular}

\section{Conclusion}

It is concluded from the results of the research that the addition of increased pectin concentrations of $1 \%, 3 \%$, and $5 \%$ gave a significant influence on water concentration and antioxidant activity of the functional food of nori derived from cassava leaves.

\section{Acknowledgement}

The research was successfully conducted due to the support of Dirjen Dikti Republik Indonesia (General Directorate of Higher Education of the Republic of Indonesia) through Program Kreativitas Mahasiswa 2016 (the 2016's Student Creativity Program Fiscal Year 2017).

\section{References}

[1] Korringa, P. (1976). Farming marine organism low in the food chain. Amsterdam, Oxford, New York: Elsevier Scientific Publishing Company.

[2] Rahmawati, Aulia, A., Nurminabari, I.S., \& Achyadi, N.S. (2016). Pengaruh perbandingan penambahan daun katuk dan lama pengeringan terhadap karakteristik fruit nori pisang (Musa Paradisiaca Formatypica) (Unpublished bachelor's thesis). Universitas Pasundan, Bandung.

[3] Nurani, F., Dhalika, T., \& Budiman, A. (2015). Mekanisme produksi protein asal daun singkong (Manihot Utilisima) sebagai bahan pakan dengan menggunakan metode pelarutan pada suhu yang berbeda. Bandung: Faculty of Animal Husbandry of Universitas Padjadjaran.

[4] Setiyaningsih, D.,Apriyanto, A., \& Puspitasari, M. (2010). Analisis sensoris. IPB Press. Bogor.

[5] AOAC. (1995). Official methods of analysis. Association of Official Analytical Chemistry. Washington DC.

[6] Putri, I. R., Basito, \& Widowati, E. (2013). Pengaruh konsentrasi agar-agar dan karagenan terhadap karakteristik fisik, kimia, dan sensori selai lembaran pisang (Musa paradisiaca L.) varietas Raja Bulu. Jurnal Teknosains, 2 (3), 112-120.

[7] Molyneux, P. (2004). The use of the stable free radical diphenylpicryl-hydrazyl (DPPH) for estimating antioxidant activity. Songklanakarin J. Sci. Technol, 26(2). 